Communicative Language Teaching の実現を促す英語科組 織の経営特性一高等学校の英語科経営に関する質問紙調査 を通して一

\title{
(Organizational Effectiveness of Upper Secondary School English Language Departments and Their Commitment toward Communicative Language Teaching)
}

\section{山森直人（やまもりなおと） 鳴門教育大学}

Since 1970, Communicative Language Teaching (CLT) has developed as a predominant trend in the world of second language teaching. CLT has had an enormous influence on theoretical aspects of second language teaching, but there has not been much evidence of change in its practical application. In the academic area of English language education research, the major focus has been on methods of instruction, teaching content, and political aspects. However, little attention has been paid to how English language education is carried out in an organized manner among the personnel of English language departments (EL departments) in Japanese schools. In order to understand the organizational characteristics appropriate to CLT practices, this study investigates (1) the realities of EL department members' commitment to CLT in public upper secondary schools in Japan, (2) the organizational characteristics of EL departments, and (3) the relationship between the organizational characteristics and the commitment to CLT

The framework to analyze organizational characteristics of the EL departments was constructed based on the theory of organizational science and research of effective schools, which consists of four criteria: adaptability, goal rationality, collegiality, and orientation. Adaptability is a criterion to assess the flexibility of EL departments in adapting to their external environments and their creativity in the face of a changing world. Goal-rationality is a criterion to assess levels of goal-attainment through the PDS cycle; setting department objectives and plans to attain them (Plan), carrying them out (Do), and evaluating them (See). 
Collegiality refers to the assessment of the efficiency of the management, and collaboration among the members of EL departments. Orientation refers to the assessment of the maintenance of the value patterns shared among the members, levels of morale, and commitment to develop the quality of their English language education. The framework for CLT is based on Kumaravadivelu's (1994) macrostrategies.

To collect data about the realities of organizational characteristics of EL departments and CLT practices, a questionnaire was administered at 128 upper secondary schools in the Chugoku area. The data of 82 schools were finally used to analyze their relations.

As a result, the following conclusions were reached:

(1) CLT can be divided into two types: activity-based CLT and form-based CLT. In most schools, both types are considered as ideal ways of teaching the language, but considering the relatively small proportion of schools where CLT is put into practice, it seems to be difficult to apply them under the present organizational conditions of EL departments.

(2) The organizational characteristics of EL departments can be grasped from the four criteria: adaptability, goal-rationality, collegiality, and orientation, and they are different from school to school.

(3) The four organizational characteristics were confirmed to promote CLT practices. Orientation and goal-rationality are especially crucial to realize CLT. In terms of CLT types, form-based CLT can be rationally put into practice through the PDS management cycle, but to realize activity-based CLT, which has been recently called for in the Japanese Course of Study, it is not enough to introduce such a rational approach, but it furthermore requires collaboration in which teachers exchange and share their trials and errors in these practices and conceptualize their own CLT.

高等学校の英語科組織の経営特性と、英語科教員のCommunicative Language Teaching(CLT)へのコミットメントの現状を質問紙調査を通して把握し、CLTの 実現を促す英語科組織の経営のあり方を追求することを目的としている。調査 票は教育経営学や組織研究などの知見をもとに作成され、英語科組織の4つの 経営特性(適応性、目標合理性、連帯性、志向性)とその成員のCLTへのコミッ トメントに関する質問項目から構成された。分析の結果、1)CLTの実現には英 語科教員の意識レベルのコミットメントを促すような職場噮境が必要であるこ と、2)4つの経営特性はCLTの実現に有効に働きかけること、3)特に活動重視型 CLTの実現は合理的な運営方式のみでは不十分であり、英語科組織成員がお互 いの経験や問題意識を共有することを通じて状況に応じたCLTを創っていくこ とが必要であること、などが明らかにされた。

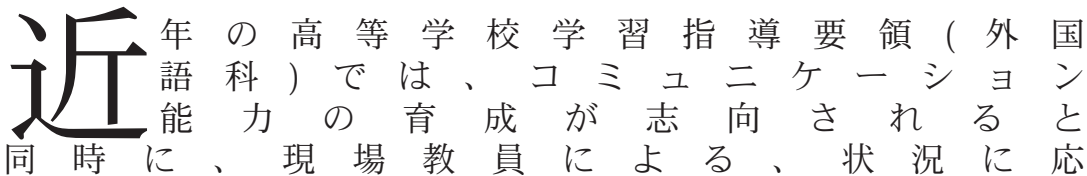
じた柔軟な指導ができるように、指導上の様々な規制が緩和されてき た。その徵候は、英語の指導内容や方法、科目数など学習指導要領の 様々な面に伺うことができる。その一方で、和田(1998)は、この「柔 軟」を「自由」あるいは「自律」と受け止めるか、「混沌」と受け止 
めるか、英語教員の自律性の問題を考える必要性があることを指摘し ている。しかし、これまでの英語教育研究では、指導方法や内容に焦 点が当てられてきたが、同じ学校に属する英語科教員の集団であり現 場の英語教育を裁量する主体である「英語科組織」が状況に応じた学 校固有の問題にいかに対処して英語教育を経営していくのかというこ とに関しては殆ど議論されてこなかった。このような現実を踏まえ、 山森(2000b)では英語科組織の経営の必要性を説き、山森(2000a)では そのあり方を考慮すべく英語科組織の有効性の指標を構築した。そ こで本稿は、その有効性指標とコミュニケーション志向の英語教育 (Communicative Language Teaching: 以下、CLTと略す)との関連を探る ことを通して、英語科組織の経営のあり方を実証的に追求することを 目的としている。

\section{英語科組織の有効性}

英語科組織はいかなる状態の時に「有効である」と言えるのであろう か。組織論や経営学では、組織の能力を包括的に呼ぶ言葉として「有効 性(effectiveness)」という用語が使用されている。しかし、この有効性の 概念を把握するための基準は多様でかつ同定するのは難しい(Cameron \& Whetten, 1983)。例えば、Steers(1975)やCampbell(1977)は有効性に関 する先行研究を概観し、それまで扱われていた多数の有効性指標を提 示している(適応性・柔軟性、生産性、満足度など)。

このような指標を整理するためにQuinn \& Rohrbaugh (1983)は有効 性に関する 3 つ価值次元を提示している。まず第 1 の次元「焦点」 は、組織の関心が組織内部にあるのか、外部にあるのかを示してい る。組織関心が内部にある場合、組織は社会・技術的システムとみな され、組織成員は、好き嫌いなどの独特の感情をもち、職場での語ら い、適切な情報、そして安定性を要求する。一方、組織関心が外部に ある場合は、組織はその使命の達成や組織資源を獲得するといった目 標を果たすためにデザインされた道具とみなされる。次に第 2 の次元

「構造」は、組織の柔軟性と安定性を両極にもつ。前者は革新と変化 をその中心的な価值とし、多様性や個々人の直感、適応性が強調され る。一方、後者は秩序と制御をその中心的な価值とし、権威や構造、 調整などが強調される。そして第 3 の次元「目的か方法か」は、組織 の有効性をその目的の到達度とみるか、到達過程とみるか、という次 元である。以上の次元を組み合わせQuinn \& Rohrbaugh (1983)は 4 つの 有効性指標を提示している。山森(2000a)ではこの指標に基づき英語科 組織の有効性の枠組みを構築した(図 1 )。

「適応性」は、学校内外の環境、あるいは社会的状況や要望などに 英語科組織や英語教育がどれだけ柔軟に適応しているかを示す経営特 性、「目標合理性」は、目標を設定し、それを達成するための合理的 な計画やその実行、結果の評価を通して、目標を達成しているかを示 
す経営特性、「連帯性」は、英語科教員同士の協働的活動が組織・実 践されているかを示す経営特性、「志向性」は、英語科教員の間に共 有される、英語授業や経営のあり方に関する価值観や、英語教育の質 を高めようとする士気が維持されているかを示す経営特性、である。 以上を考慮すれば、これまで英語教育の経営的側面は目標合理性のみ から捉えられてきたといえよう。しかし、同指標に基づけば、英語科 組織の経営特性をより包括的に把握できると同時に、経営の方向性を 多角的に示すことが可能である。

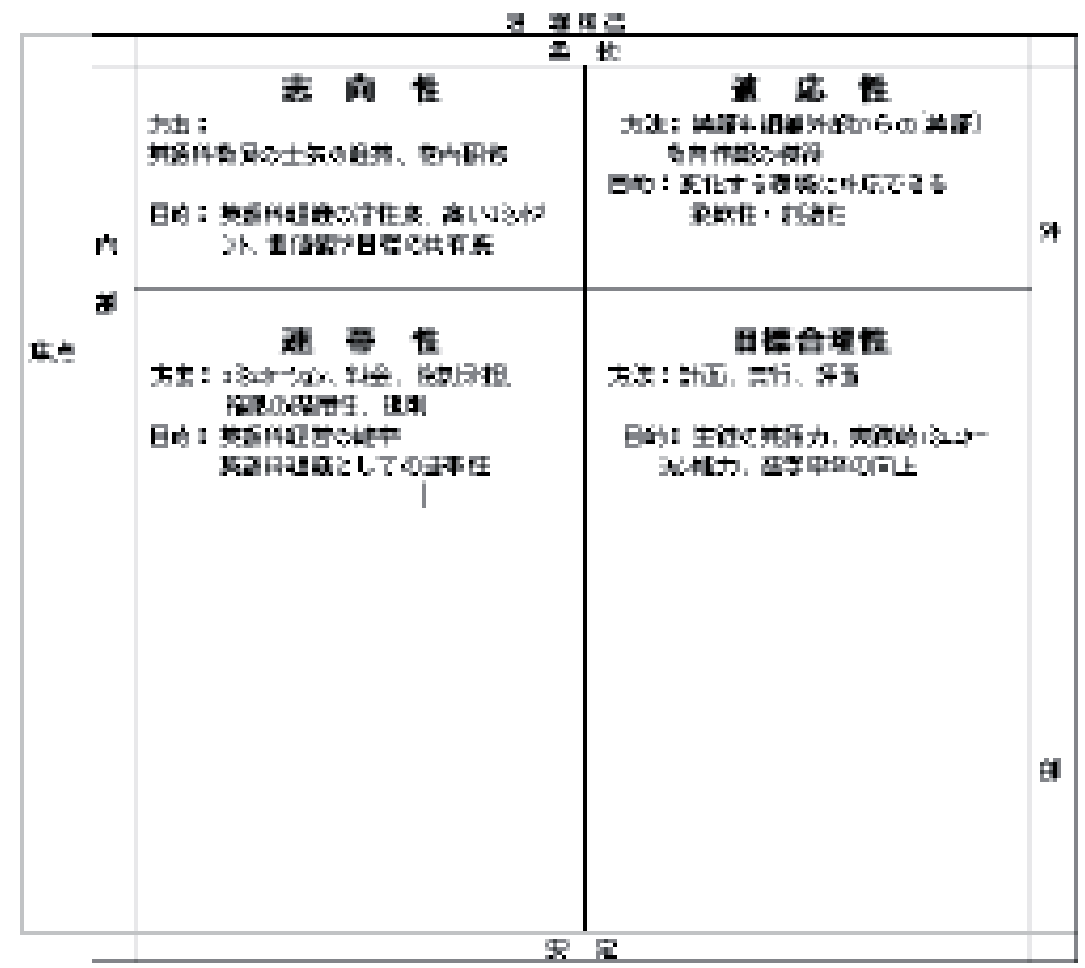

英語科組織の経営特性とCLTとの関連

それでは、以上の 4 つの経営特性はコミュニケーション志向の英語 教育(CLT)の実現に有効に動きかけるのであろうか。ここでは、高等 学校における英語科組織の経営特性とCLTとの間にある関係を解明す ることを目的に実施した質問紙調査の結果を報告する。 
調査課題

1)英語科教員のCLTへのコミットメントの現状の把握。

2)英語科組織の経営特性の現状の把握。

3)英語科組織の経営特性とCLTへのコミットメントとの関係の解明。

\section{調查 \\ 調査手法}

郵送法による質問紙調査。2000年7～9月実施。

\section{調査対象}

中国地区 (5県)に在する公立高等学校(全309校一普通高校と専門高校 の比率は74\%と26\%)の英語科教員を調査対象とした。最終的に128校(回 収率 $41 \%)$ (19名分の回答を有効データとして扱った。同標本校数は信 頼度が95\%で誤差幅7\%、普通高校と専門高校の比率はそれぞれ70\%と 30\%であり、後述する因子分析ではこれらのデータを全て用いた。

\section{分析枠組み}

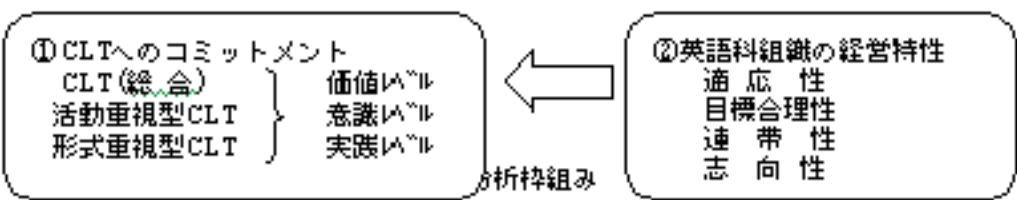

図 2 は本調査の分析枠組みを示している。まず(1)CLTへのコミット メントと(2)英語科組織の経営特性の現状を把握し、その後、両者の関 係を分析する。(1)CLTへのコミットメントに関する質問項目は、Kumaravadivelu(1994)のマクロストラテジー(see 山森, 1999)を、学習指導 要領などをもとに日本の英語教育の現状に合うように調整・項目化し たものであり、各項目を価值レベル(重要だと思うか)、意識レベル(勤 務校において意識しているか)、実践レベル(実際に実践しているか)の 観点から尋ねている(表 1)。また、(2)英語科組織の経営特性に関する 質問項目は、図 1、及び、Rosenholtz (1991)などの効果的学校研究の 成果をもとに作成された(表 6 )。

\section{分析手法}

質問項目は、「全くそうである」から「全くそうでない」の 7 段階 のリカート方式により回答が求められた。各回答に対し 7 点〜 1 点の 点数を与え回答者の得点とし、この得点をもとに統計分析を施した。 まず、図 2 の(1)と(2)それぞれの質問項目群ごとに因子分析を実施し 
た。次に回答者が質問項目に与えた得点を抽出因子ごとに合計し、項 目数で除すことにより算出した数值を回答者個人の得点とした。本調 査では組織単位の実態把握を主眼としていることを踏まえ、回答者個 人の得点をもとに英語科組織(学校)ごとの平均得点を算出し、対象校 の代表值とした。ただし、代表值が対象校の現状を反映するにはある 程度の人数が必要であることを考慮に入れ、英語科組織成員の半数以 上から回答が得られた高校のみをその後の分析の対象とした。最終的 に82校の英語科組織がこの基準を満たし、同標本は信頼度95\%で誤差 幅10\%、普通高校と専門高校の比率は63\%と37\%となった。

結果と考察

CLTへのコミットメントの現状

表 1 はCLTへのコミットメントに関する各質問項目である。

\begin{tabular}{|c|c|}
\hline 置 問 愐 & 称 \\
\hline 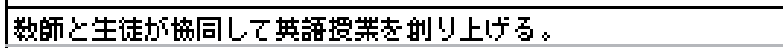 & 学畂棁会最大化 \\
\hline 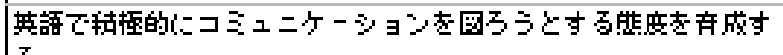 & \\
\hline & 意思伝诖貿度 \\
\hline コミュニケーション活的意可眼な限り実嗾する。 & 意味交啮促進 \\
\hline 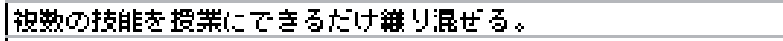 & 4 技覞䋨合 \\
\hline 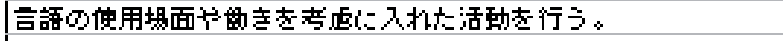 & 言語文服化 \\
\hline 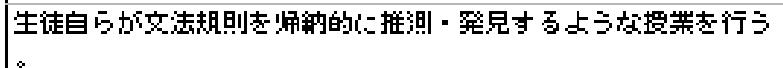 & 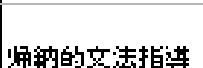 \\
\hline 其語の文法规則し対する分析的な力を莣うような文法指萁を行う & 言語意諈化 \\
\hline 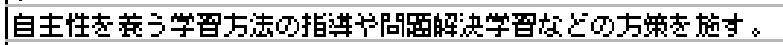 & 自律性 \\
\hline 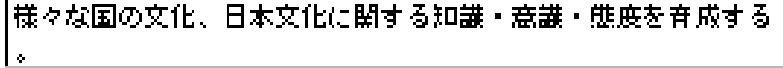 & 署文化理昭 \\
\hline 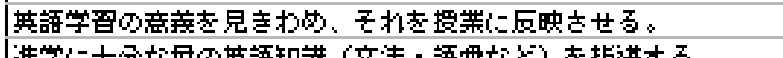 & 社全認詇 \\
\hline
\end{tabular}

まず、各質問項目に与えられた点数をレベル(価值、意識、実践)ごと に合計した1。この合計点はあらゆる要素を含んだCLTへのコミットメ ントの度合いを表し、以下では「CLT(総合)」と呼ぶ。そして、レベル 間の平均值の差が統計的に有意か確認した(反復測定分散分析)。その 結果、各レベルの効果は有意であり $\left(\mathrm{F}_{(2,1254)}=228.29, \mathrm{p}<.001\right)$ 、多重比較 によれば、価值 $>$ 意識 $>$ 実践の順であった $(\mathrm{MSe}=80.76, \mathrm{p}<.05)$ 。以上の 結果は、英語科教員が理想としているCLT(価值レベル) と、現場の状 況を踏まえて意識されるCLT(意識レベル)、実際に実践されるCLT(実 践レベル)は異なること、及び、CLTに対するコミットメントは価值 レベルでは高いが、意識レベル、実践レベルの順に低くなることを示 唆している。

次に、コミットメントのレベル間の相関関係を求めた結果、価值と意 
識レベルには中程度の正の相関 $(\mathrm{r}=.49, \mathrm{p}<.001)$ 、意識と実践レベルには 強い正の相関 $(\mathrm{r}=.85, \mathrm{p}<.001)$ 、価值と実践レベルには弱い正の相関 $(\mathrm{r}=.27$, p<.001)が確認された(表 2)。この結果は、CLTの実践(実践レベル)は、 教員の理想的なCLT像(価值レベル)というよりも現場状況に応じて意識 されるCLT像(意識レベル)に強く規定されることを示唆している。

\begin{tabular}{|c|c|c|c|c|}
\hline & \multicolumn{2}{|c|}{ 咅楛 $1 \mathrm{~A}^{2} \mid \mathrm{l}$} & \multicolumn{2}{|c|}{ 宝跣 $1 \mathrm{~A}^{2} \mathrm{ll}$} \\
\hline 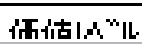 & .49 & Hatal: & .27 & Hatat: \\
\hline 竞楛心 ${ }^{n} \mid$ & & & .85 & Hatak: \\
\hline
\end{tabular}

さらに、CLTの実践を規定すると考えられる意識レベルの質問項目 に与えられた得点をもとに因子分析を実施した。その結果、2つの因 子が抽出された(表 3 )。

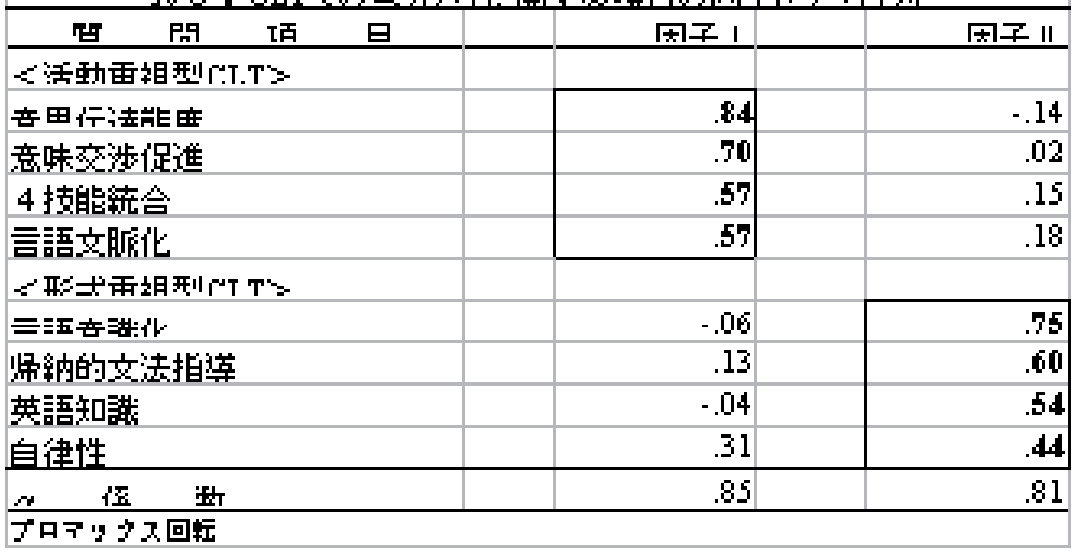

各因子を構成する質問項目より、第 I 因子は、意味ある場面におけ る 4 技能を統合した言語活動を通して、コミュニケーションを図ろう とする態度を養うことを示しているため「活動重視型CLT」と名付け られた。この種のCLTは、生徒の言語「使用」に焦点があり、近年の 学習指導要領において実現が強調されている指導法でもある。一方、 第 II 因子は、英語の知識(文法や語彙)の指導の中でも生徒の自発性を 尊重し、生徒自身が主体的・帰納的に言語構造を構築する能力を養う ことを示しているため「形式重視型CLT」と名付けられた。この種の CLTは、生徒の言語に対する意識や分析力を養うことに焦点があり、 従来の機械的な知識詰め込み型の文法指導とは性格を異にする。以上、 抽出された因子ごとに質問項目に与えられた点数を合計し、項目数で除 すことにより得られた数值を回答者個人の得点とした。

コミットメントのレベル間の平均值の差が統計的に有意か確認した 結果 (反復測定分散分析)、各レベルの効果は有意であり (活動重視型 
CLT: $F_{(2,1254)}=234.66, p<.001$, 形式重視型CLT: $\left.F_{(2,1254)}=130.75, p<.001\right) 、$ 多 重比較によれば、両者ともに価值>意識>実践の順であった(活動重視型 CLT: MSe=1.03, p<.05, 活動重視型CLT: MSe=1.02, p<.05)。ここでもコミ ットメントに 3 つのレベルが存在することが確認された。

次に、活動重視型CLTと形式重視型CLTそれぞれにおけるコミット メントのレベル間の相関係数を算出した結果、価值と実践レベルの相 関関係が前者では低い相関(r=.25)であった(表 4)のに対し、後者では中 程度の相関 $(\mathrm{r}=.40)$ があった(表 5$)$ 。これは、活動重視型CLTは理想とし て認識されていたとしても、形式重視型CLTに比べ、現実の指導方法と して意識、あるいは実践され難いことを示唆している。

\begin{tabular}{|c|c|c|c|c|}
\hline & 咅灌 & $\left|A^{n}\right| k$ & 宝踏 & $\left|A^{n}\right| k$ \\
\hline 伍估|A II & .46 & Hatak: & .25 & Hatak: \\
\hline 意讙ばリ & & & .82 & Hatak: \\
\hline
\end{tabular}

\begin{tabular}{|c|c|c|c|c|}
\hline & \multicolumn{2}{|c|}{ 咅楛: $1 \alpha^{2} \mid l$} & \multicolumn{2}{|c|}{ 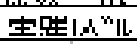 } \\
\hline 伍估|A & .52 & Hatas: & .40 & Hatak: \\
\hline 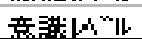 & & & .89 & Hotas: \\
\hline
\end{tabular}

最後に、CLT(総合)、活動重視型CLT、形式重視型CLTへのコミット メントそれぞれに対して回答者が与えた得点から学校ごと(82校)の平均 得点を算出した。そして、各学校を高得点群、中間点群、低得点群に 分類し、その割合を図式化した(図 3〜 5)。

CLT(総合)、活動重視型CLT、形式重視型CLTのいずれの意識レベル においても過半数(72\%,79\%,61\%)の学校が高得点群に属していること から、CLTが学校現場に浸透してきていると言えよう。しかし、価值、 意識、実践レベルという順で高得点群の割合が減少し、逆に中間点群 と低得点群の割合が増加している。これは、各校の英語科教員が掲げ る英語教育の理想像は高いが、それを現状では十分に実現できていな いことを示唆している。その原因として、学校の環境的要因(教員の多 忙さ、生徒の雰囲気など)やCLTの技術的困難さなどが考えられる。そ のような要因を含め、CLTが実現されている学校ではどのような英語科 経営がなされているのかを検証する必要がある。

\section{英語科組織の経営特性の現状}

英語科組織の経営特性に関する質問項目について因子分析を実施し、 予測された因子数や寄与率などから 4 つの因子が抽出された(表 6 )。各 因子を構成している質問項目より、第 I 因子は志向性、第 II 因子は連帯 

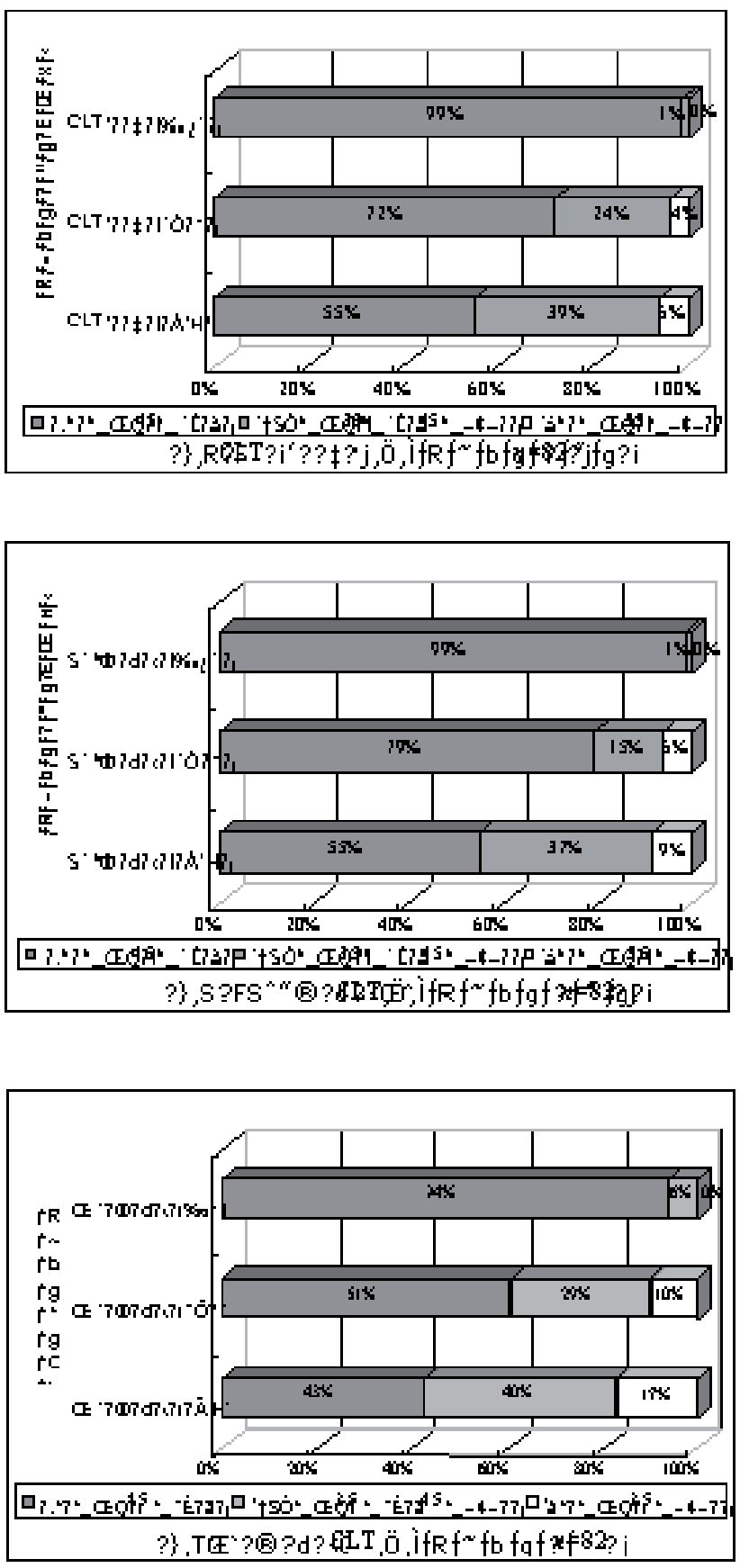
性、第而因子は目標合理性、第IV因子は適応性、を示していることが分 かる。また、各経営特性を構成する質問項目の内的一貫性をクロンバッ クの $\alpha$ 係数により算出した結果、高い信頼性が確認された(表 6 )。

次に、各経営特性に対して回答者が与えた得点から学校ごと(82校)の 平均値を算出し、対象校を高得点群、中間点群、低得点群に分類し、 その割合を図式化した(図6)。

適応性と目標合理性に関しては、中間点群が過半数を占め $(57 \%$ と 51\%)、残りは高得点群と低得点群に二分化し、連帯性と志向性は高得 点群の割合が非常に高い $(91 \%$ と $72 \%)$ 。多くの英語科組織では外部情 報を獲得し、それに適応するために、英語教育の目標や計画を立て、 実行、評価するという一般に考えられる経営が必ずしもなされていな いことが伺える。その一方で、英語科教員同士の協力関係は高く、英 語指導の質的向上に関して意欲的な学校が多いことが分かる。

\begin{tabular}{|c|c|c|c|c|c|}
\hline & $1 \mathrm{H}$ & 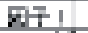 & 田王 & Fif & I 7 ir \\
\hline & 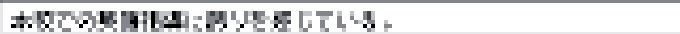 & H & נבי. & 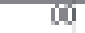 & 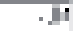 \\
\hline $\mathrm{z}$ & 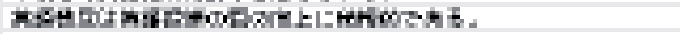 & di & .12 & $=10$ & E \\
\hline \multirow[t]{2}{*}{ 뭉 } & 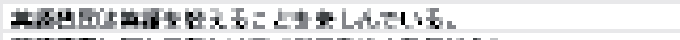 & A & - It & L & - \\
\hline & 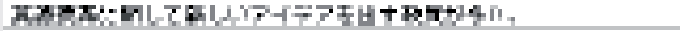 & If & II & -00 & I: \\
\hline \multirow[t]{2}{*}{ 诖 } & 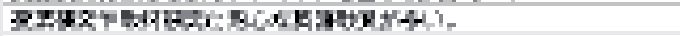 & $I$ & . I. & $-\infty$ & I \\
\hline & 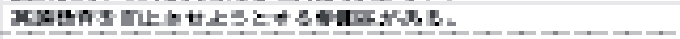 & th & .7 & 10 & I: \\
\hline \multirow{4}{*}{$\frac{t}{4}$} & 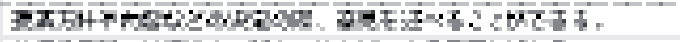 & -18 & \pm & $=4$ & - $1 \mathrm{k}$ \\
\hline & 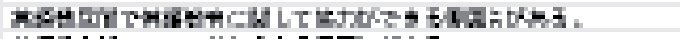 & $=4$ & I & 15 & F \\
\hline & 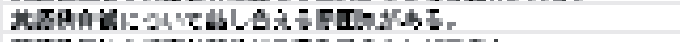 & it. & 91. & $-6 \mathbf{I}$ & - $\mathbf{F}$ \\
\hline & 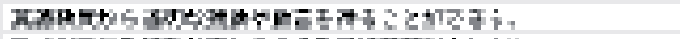 & 9 & 11 & -0 & \pm \\
\hline \multirow[t]{2}{*}{1} & 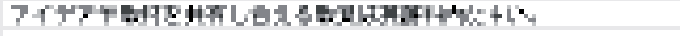 & M & 54 & 6 & I: \\
\hline & 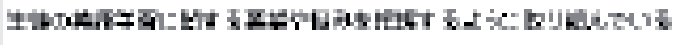 & & & & \\
\hline \multirow{7}{*}{$\frac{1}{8}$} & 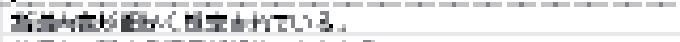 & $-\pi$ & - I5: & It & I: \\
\hline & 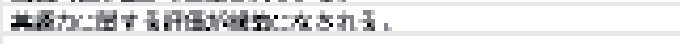 & $-m$ & 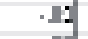 & 7 & a: \\
\hline & & & 13 & 4 & .I: \\
\hline & 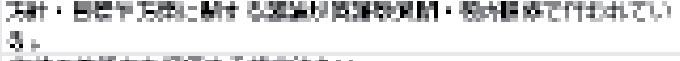 & & & & \\
\hline & 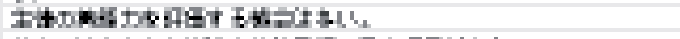 & WL & I & g & ; \\
\hline & 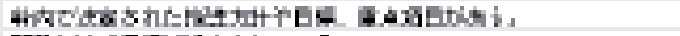 & 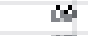 & $\amalg$ & S & I: \\
\hline & 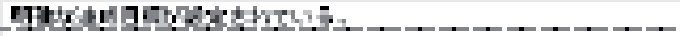 & $\pi$ & II & 4 & H \\
\hline \multirow{2}{*}{5} & 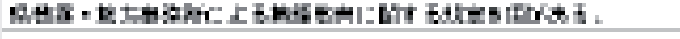 & $-\infty$ & - DI & $=11$ & I \\
\hline & 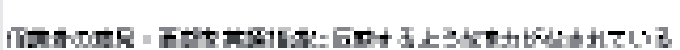 & His & . & -1 & $2 \%$ \\
\hline & 11. & & & & \\
\hline \multirow{7}{*}{ ti } & & $\sigma$ & ] I] & 19 & It \\
\hline & 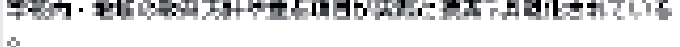 & & & & \\
\hline & 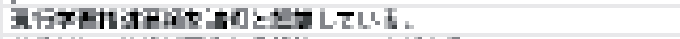 & $=01$ & I] & -1 & 혀 \\
\hline & 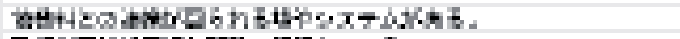 & -0 & 77 & 0 &. \\
\hline & 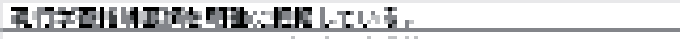 & $\sigma$ & $1]$ & $\Delta$ & at: \\
\hline & 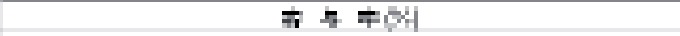 & It & [1] & E & $\Xi$ \\
\hline & $\pi+8$ & H. & 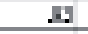 & J. & $\pi$ \\
\hline \multicolumn{2}{|c|}{ 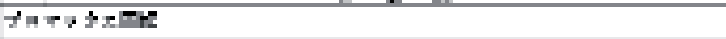 } & & & & \\
\hline
\end{tabular}


英語科組織の経営特性とCLTへのコミットメントとの関係 英語科組織の経営特性とCLTへのコミットメントとの関係を明らか にするために相関分析を実施した。

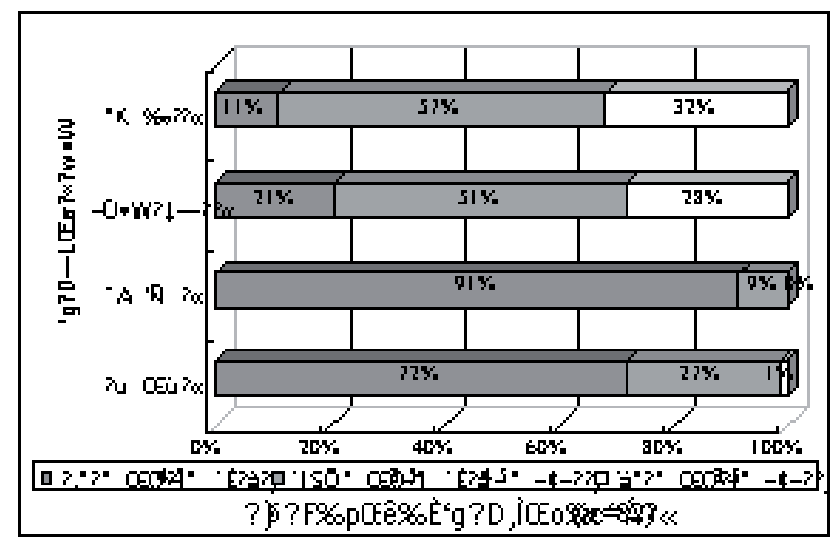

英語科組織の経営特性とCLT(総合)へ のコミットメントとの関係

価値レベルに関しては、連帯性( $\mathrm{r}=.41, \mathrm{p}<.001)$ と志向性(r=.51, $\mathrm{p}<.001)$ に 比較的高い正の相関が確認された。また、意識と実践レベルに関して は、目標合理性 $(\mathrm{r}=.44, \mathrm{r}=.44$ ともに $\mathrm{p}<.001)$ と志向性 $(\mathrm{r}=.60, \mathrm{r}=.53$ ともに $\mathrm{p}<.001)$ に比較的高い正の相関が、適応性 $(r=.26, \mathrm{p}<.05, \mathrm{r}=.30, \mathrm{p}<.01)$ と連 帯性( $(\mathrm{r}=.34, \mathrm{r}=.33$ ともにp<.01)に低い正の相関が確認された(表 7 )。

以上の結果は、CLT(総合)が実施されている英語科組織は、適応性、 目標合理性、連帯性、志向性が強いことを示しており、これらの経営特 性を高めることで、CLT(総合)へのコミットメントが意識・実践レベル において促されることを示唆している。特に、目標合理性と志向性は CLTの意識・実践レベルのコミットメントとの関係が強く、CLTの実 現には英語指導の質を高めていこうとする英語科教員の士気と共に、 それを、計画一実行一評価という合理的経営のなかで実現していく必 要性が示唆された。 


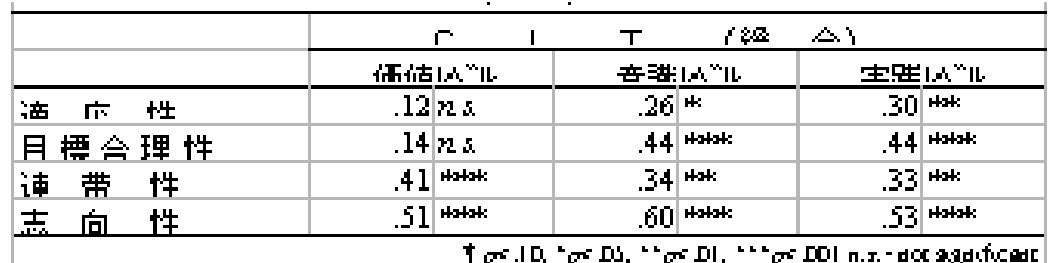

英語科組織の経営特性（活動重視型と形式重視型）

$$
\text { へのコミットメントとの関係 }
$$

まず、志向性には、活動重視型CLTと形式重視型CLTの全レベルに 対し、比較的高い正の相関(活動重視型CLT: $r=.44, r=.56, r=.48$, 形式重 視型CLT: $\mathrm{r}=.44, \mathrm{r}=.51, \mathrm{r}=.49$, いずれも $<$.001)が確認された。次に、目標 合理性には、活動重視型CLTの意識・実践レベルに低い正の相関 $(\mathrm{r}=.33$, $\mathrm{r}=.33$, ともに $\mathrm{p}<.01)$ が、形式重視型CLTには比較的高い正の相関( $\mathrm{r}=.57$, $\mathrm{r}=.61$, ともに $\mathrm{p}<.001)$ が確認された。また、価值レベルにおいては、活動 重視型CLTとに相関が認められなかったが、形式重視型CLTとには、低 い正の相関 $(r=.23, \mathrm{p}<.05)$ が確認された。適応性には、活動重視型CLTと の間に十分な相関が認められず、形式重視型CLTの意識・実践レベル との間に低い正の相関 $(r=.36, p<.001, r=.34, p<.01)$ が確認された。最後 に連帯性には、活動重視型CLTの全レベルに対し、低い正の相関 $(\mathrm{r}=.37$, $\mathrm{r}=.38$, ともに $\mathrm{p}<.001, \mathrm{r}=.30, \mathrm{p}<.01)$ が確認され、形式重視型CLTとの間に は価值レベルのみに低い正の相関( $\mathrm{r}=.29, \mathrm{p}<.01)$ が確認された(表 8$)$ 。

以上をまとめるならば、英語科組織の志向性は活動重視型CLTと形式 重視型CLTを同じように促すが、適応性は形式重視型CLTを、連帯性は 活動重視型CLTを促す。また目標合理性は両者を促すが、その傾向は形 式重視型CLTにおいて強い。これは、1)志向されるCLTの類型(活動重視 型か形式重視型)に応じて英語科組織の 4 つの経営特性が果たす役割が 異なること、2)形式重視型CLTは英語科組織の外部環境への適応活動を 通じて生み出され、活動重視型CLTは英語科組織内部における教員同士 の協働を通じて生み出されること、及び、3)形式重視型CLTに比べ、活 動重視型CLTは、目標化あるいは評価し難いためか、計画一実行一評価

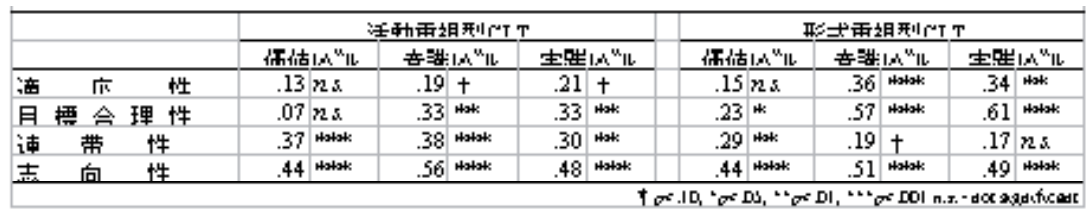

といった経営方式にはなじみ難いこと、を示唆している。 
英語科組織の経営特性とCLTの類型の対応関係

経営特性と各校で志向されるCLTの類型との対応関係を一層明確に 確認するために、活動重視型CLTと形式重視型CLTへのコミットメン 卜(意識レベル)の平均值をもとに、対象校を、活動重視型CLTと形式 重視型CLTの両者を志向する学校(統合型: 33校)、前者のみを志向する 学校(活動重視型: 10校)、後者のみを志向する学校(形式重視型: 12校)、 ぞちらも志向していない学校(不完全型: 27 校)、の 4 つに類型化した。 図 7 は各類型に属する英語科組織の経営特性の平均值(平均値0, 標準偏 差1に標準化)を表している。

類型別の主効果は、有意傾向を示した適応性 $\left(\mathrm{F}_{(3.78)}=2.50, \mathrm{p}<.10\right)$ を除 $<$ 、目標合理性 $\left(\mathrm{F}_{(3.78)}=6.53, \mathrm{p}<.001\right)$ 、連帯性 $\left(\mathrm{F}_{(3.78)}=4.58, \mathrm{p}<.01\right)$ 、志向性 $\left(\mathrm{F}_{(3.78)}=7.73, \mathrm{p}<.001\right)$ において有意であった。多重比較より、目標合理性

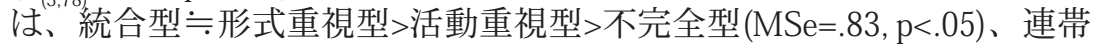
性は、活動重視型 $\fallingdotseq$ 統合型>形式重視型 $\fallingdotseq$ 不完全型 $(\mathrm{MSe}=.88, \mathrm{p}<.05)$ 、志

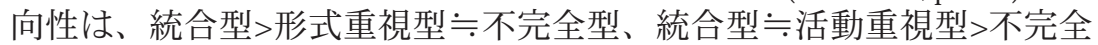

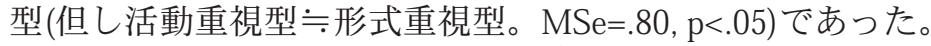

以上の結果に考察を加える。まず、適応性に関しては、志向される CLTの類型による英語科組織間の統計的な相違はみられなかった。し

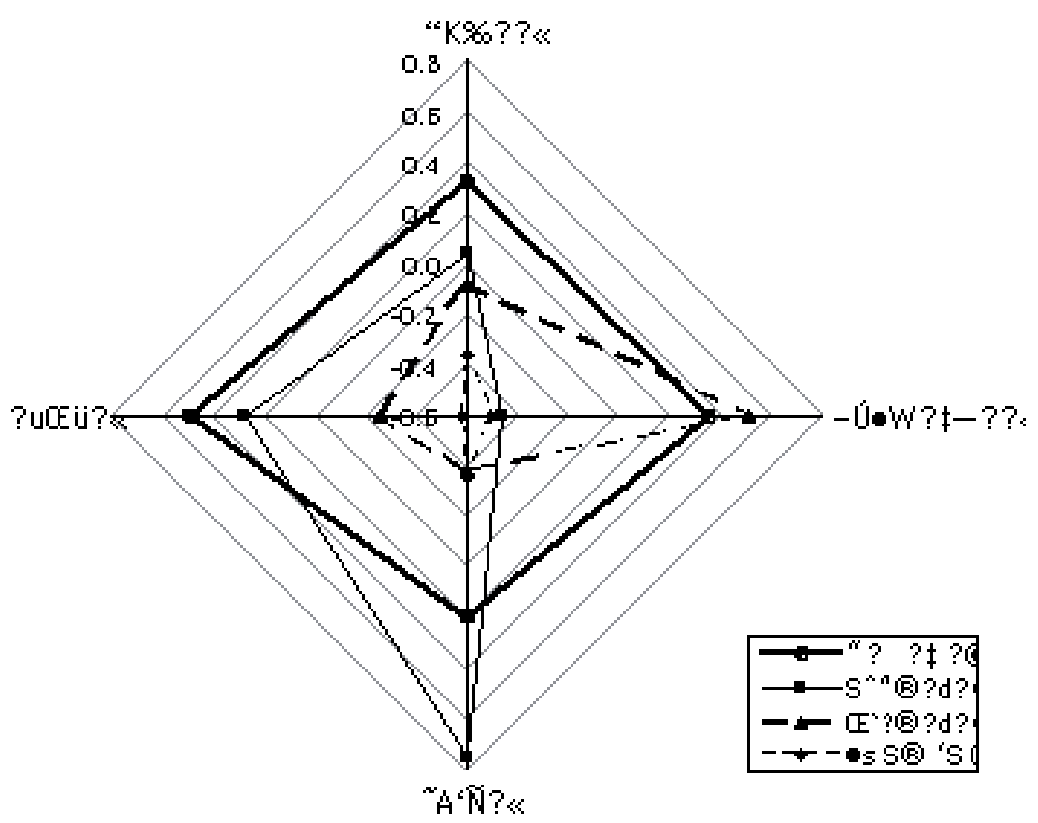

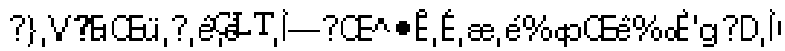


かし、表 8 の相関分析において形式重視型CLTと適応性に有意な相関 関係が確認されたことを踏まえれば、活動重視型CLTに比べ、形式重 視型CLTは外部情報として、英語科組織に吸収されやすく、具現化が 容易であることを示唆している。また形式重視型CLTのみが志向され る英語科組織では連帯性が低く、目標合理性が高いのに対し、活動重 視型CLTのみが志向される英語科組織では連帯性が高く、目標合理性 が低い。これは、活動重視型CLTは形式重視型CLTに比べ、計画一実 行一評価という一連の流れにおいて具現化され難く、それを促すには 英語科教員同士がお互いの経験を共有し、自分たちのCLTを創造して いくような協働関係が必要とされることを示唆している。

\section{結 論}

本調査の結果から高等学校の英語科経営について次のような提案が できる。

高等学校におけるCLTの実践は、教員の理想的なCLT像というより も現場状況に応じて意識されるCLT像に強く規定されることが示唆さ れた。従って、CLTの実現には、英語科教員が教育現場を踏まえて CLTをいかに解釈しているのかを解明すること、及び、その解釈のあ り方がより適切な方向に促されるような現場環境、すなわち英語科組 織の経営特性を開発することが必要である。

そのような英語科組織の経営特性として、適応性、目標合理性、連 帯性、志向性があり、これらの特性を育てることが必要である。

より具体的には、英語の形式的側面の学習を中心に据えたCLTは、 英語科組織の合理的な経営によって、すなわち、学校を取り巻く環境 を踏まえた目標や指導計画を設定し、実行後、その結果を評価し、次 の指導に活かすことで、その質を高めることができる。これに対し、 近年とみに叫ばれるコミュニケーションを図る態度の育成や、コミュ ニケーション活動の促進、4 技能の統合など、活動を重視したCLTを 実現するには、そのような合理的な経営方式のみでは不十分であり、 英語科組織の成員同士が、その種の英語教育の実現のために、お互い の経験を共有し試行錯誤を通じて、所属校の状況に合ったCLTを創り 上げていくことが必要である。

これらの経営特性を高めることで、形式重視型CLTと活動重視型 CLTの実現が促され、相乗的にコミュニケーション志向の英語教育が 実現されると考えられる。

注

1) CLTの総合得点を構成する質問項目の $\alpha$ 係数はいずれのレベルにお いても0.9以上であった。また、総合得点には「英語知識」の点数は含 まれていない。 


\section{参考文献}

山森直人 (1999) 「Communicative Language Teaching 再考一国際比較の枠組みを 求めて一」『広島大学教育学部紀要』47, 43-52

山森直人 (2000a)「高等学校の英語科組織の有効性について」全国英語教育学 会第26回自由研究発表会 (2000.8.9. 東京国際大学) 口頭発表資料.

山森直人 (2000b)「高等学校英語教育における自由裁量の余地を経営する必要性 と方向性について」『中国地区英語教育学会研究紀要』30,161-170

和田 稔 (1998)「巻頭言 自由と自律」『英語教育』50(3), 1 開隆堂

Cameron, K. S., \& Whetten, D. A. (Eds.). (1983). Organizational Effectiveness - A Comparison of Multiple Models. N.Y.: Academic Press.

Campbell, J. P. (1977). On the nature of organizational effectiveness. In P. S. Goodman, J. M. Pennings, \& Associates, New Perspectives on Organizational Effectiveness (pp.13-55). San Francisco: Jossey-Bass.

Kumaravadivelu, B. (1994). The postmethod condition: (E)merging strategies for second / foreign language teaching. TESOL Quarterly, 28 (1), 27-48.

Quinn, R. E., \& Rohrbaugh, J. (1983). A spatial model of effectiveness criteria: Towards a competing values approach to organizational analysis. Management Science, 29 (3), 363-377.

Rosenholtz, S. J. (1991). Teachers' Workplace. New York: Teachers College Press.

Steers, R. M. (1975). Problems in the measurement of organizational effectiveness. Administrative Science Quarterly, 20, 546-558.

(Received May 7, 2001; revised November 28, 2001) 